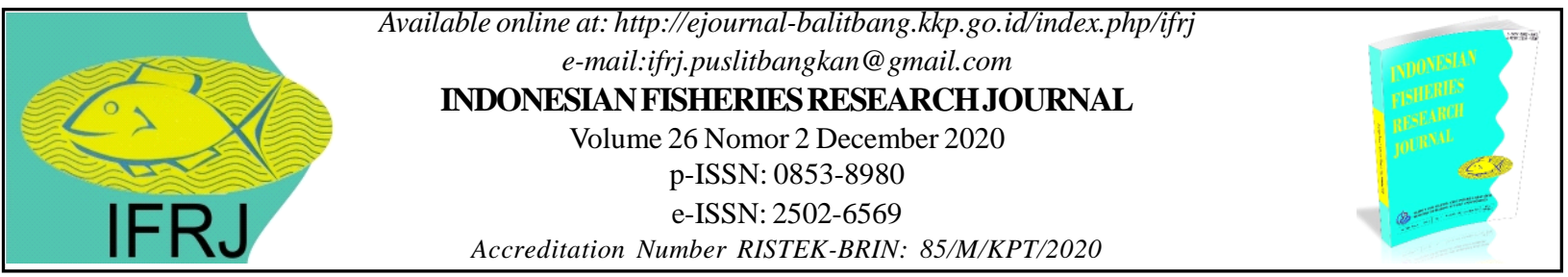

\title{
CATCHABILITY AND DIVERSITY OF FISH SPECIES CAPTURED BY GILL NET IN NEW CALABAR RIVER, NIGERIA
}

\author{
Olaniyi Alaba Olopade ${ }^{* 1}$, Henry Eyina Dienye ${ }^{1}$, Ogheneforon Oderhohwo and Nathanael Akinsafe Bamidele ${ }^{2}$ \\ ${ }^{1}$ Department of Fisheries, Faculty of Agriculture, University of Port Harcourt, Nigeria \\ ${ }^{2}$ Institute of Food Security, Environmental Resources Agricultural Research Federal University of Agriculture, Abeokuta, Nigeria \\ Received; January 10-2020 Received in revised from July 23-2020; Accepted July 27-2020
}

\begin{abstract}
The aim of this study was to analyze fish species caught by gill nets and fish diversity of the New Calabar River. Three sampling stations were set based on the coverage situation of the river and ichthyofauna associated with gill nets were sampled twice monthly from February to July 2018. A total of 3,251 fish specimens, representing 11 orders, 15 families, and 28 species, were captured. The order Perciformes was identified as the most abundant representing five families while the remaining had one family each. The fish family Cichlidae was the most represented with seven species, and other notable families were Alestidae, Clupeidae, and Mugilidae, representing three species each. Prominent among the fish caught monthly included Liza falcipinnis, Mugil cephalus, Sarotherodon melanotheron, Sarotherodon galilaeus, Coptodon guineensis, and Sardinella maderensis. The mean catch per unit effort (CpUE) ranged from $3.15 \pm 0.2$ to $4.85 \pm 0.2 \mathrm{~kg} \mathrm{unit}^{-1}$ day $^{-1}$. Results of diversity indices revealed that Shannon-Wiener index values varied between 2.64 and 2.82, Simpson diversity ranged from 0.07 to 0.10 , and Pielou's evenness index values ranged from 0.85 to 0.95 . The values obtained in this study showed that the status of fish diversity in New Calabar River was stable.
\end{abstract}

Keywords: Ichthyofauna; gill nets; diversity indices; catch per unit effort; New Calabar River

\section{INTRODUCTION}

The fisheries sector has a vital role in the Nigerian economy, even though presently its contributions to Gross National Product (GNP) is generally very low, for example it contributed only 0.5 percent of national GDP (FAO, 2007). The annual fish production in 2015 was estimated at 1,027,000 tonnes, including marine catches, inland waters catches, and aquaculture contributed $36 \%, 33 \%$, and $31 \%$, respectively (FAO, 2007). The Nigerian fisheries sector also plays major roles as the sources of employment and food security.

The country has both marine and inland waters that are rich in fisheries resources. The inland waters are very rich in fish biodiversity with about 338 freshwater fish species as recorded in Fishbase (Froese \& Pauly, 2010). The inland fisheries are exploited by small-scale fishers with simple traditional and modern fishing crafts and gears. The status of the inland capture fisheries in Nigeria is largely a result of a failure of the present process of fisheries governance which poses significant threats to the management of fisheries resources (Olopade et al., 2017a). This has brought about changes in species composition, size structure, and genetic structure of stock that have implications for the fisheries. Parameters such as species composition, species richness, and abundance have been used in many studies to describe and assess fish community and diversity (Smith, 1978).

One of the major ways of increasing yield from capture fisheries on a sustainable basis is by better management through enforceability of regulations. Fishing effort limitations have successfully proved in restoring abundance levels in the multi-species fisheries (Garcia \& Demetropoulos, 1986). The way to place embargo on the unsustainable fishing gear is to have a good knowledge of fishing gear construction, operation, and common target species (Olopade et al., 2017b). There are a wide range of gears in use depending on the species targeted, experiences, and skills of the fishers. Gill nets are common fishing gear used by small-scale fisheries in Nigerian inland waters (Solarin et al., 2003). This gear is commonly used as it is an efficient fishing gear for pelagic fish species, offers affordable price, and requires low operating cost (Clarke \& King, 1986). 
However, gill nets present serious management problems because they select what they catch primarily by size and activity pattern and a much lesser degree by characteristics which discriminate marketable species from commercially unimportant ones (Schneider, 1986). Catch analysis of gillnet fish fauna is poorly known. At present, no sufficient information is available on the types and specifications of fishing gears, species targeted, intensity of exploitation, and their influence on fish diversity and distribution pattern in the New Calabar River. Without this important information on fishery dependent factors, effective fisheries management and policymaking are impossible. This study aims to analyse the fish fauna diversity and catchment from gill nets fisheries of New Calabar River, for proper management and sustainable utilization of the fish resources.

\section{MATERIALS AND METHODS Study Area}

The study was on the stretch of the New Calabar River, Rivers State, Nigeria. Its geographical coordinates are longitude $7^{0} 60^{1} \mathrm{E}$ and latitude $4^{0} 25^{1} \mathrm{~N}$. The river originates in Rivers Niger and Benue, which eventually join at Lokoja. The river is among rivers that flow into the Atlantic Ocean. It is a partially mixed estuary river that supports a rich and diverse assemblage of commercially important fish resources.
There is a long rainy season in the region with annual rainfall ranging between 2,000 to $3,000 \mathrm{~mm}$ (Abowei, 2000) and short dry with only the months of December and January truly qualifies as dry season months with occasional rainfall. The river is a mixture of freshwater and low brackish water most of the year. Three sampling stations were set along the New Calabar River based on the coverage situation of the river. The sampling stations were Choba (S1) in the upper part of the river, Ogbogoro (S2) in the middle part, and Iwofe (S3) in the lower part of the river (Figure 1).

\section{Fish Collected}

The stations were sampled twice monthly for fish fauna associated with gill nets used by local fishermen. Sampling was done to the catch of multifilament gill nets of mesh sizes 15 and $25 \mathrm{~mm}$ used by the fishermen throughout the sampling period. All nets were set in the afternoon and retrieved in the next morning. Gillnets are colourless, made of 210D/ 3 twine where there are three strands each of the dimension 210 Denier. Each gillnet has a dimension of $25 \mathrm{~m} \times 3 \mathrm{~m}$ and a hanging ratio of 0.5 . Specimens were taken from 5 randomly selected fishermen using gill nets at each sampling site twice on a monthly basis. All the fishes were identified and sorted into species level using identification keys of Schneider (1990) and Adesulu \& Sydenham (2007).

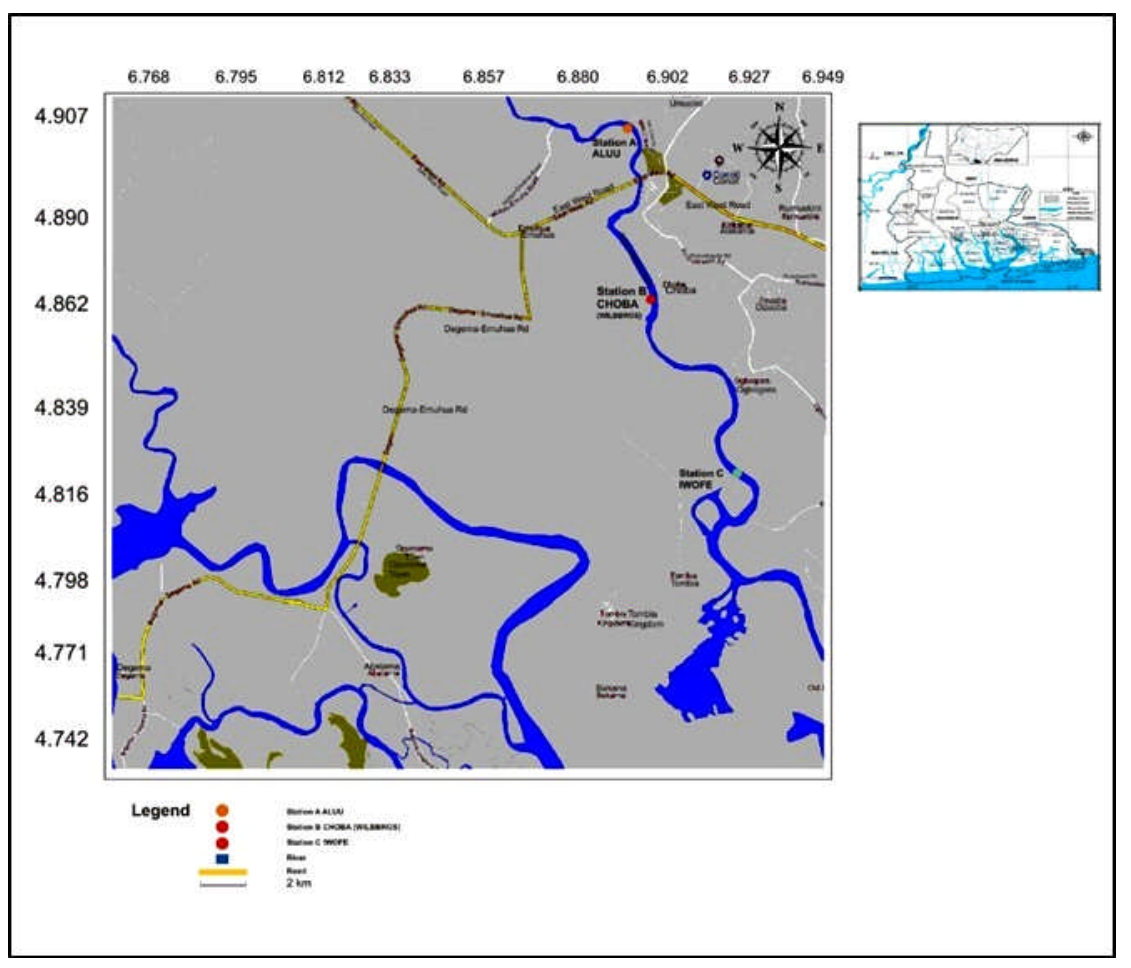

Figure 1. Map of New Calabar River showing three sampling stations. 


\section{Data Analysis}

Relative abundance was calculated as follows:

Relative species abundance $=(n / M) \times 100$ (Krebs, 1989 in Sarý et al., 2006).

Where:

$n=$ number of individuals of the species in the samples $N=$ total number of individuals of fish caught

The catch per unit effort ( $C p U E$ ) for the gill nets in the three stations were taken based on the weight of fish caught during a fishing day ( $\mathrm{kg}$ day- ${ }^{-1}$ fishing unit$\left.{ }^{1}\right)$. CpUE of monthly species caught was used in this study.

Diversity indices were calculated by ShannonWiener Diversity Index $\left[H=-O p^{*} \operatorname{In}(p)\right]$ (Shannon \& Weiner, 1949) Where $P i$ is the relative cover of ith species and $n$ is the number of individuals of each species), Simpson's index [D = " $n(n-1) / N(N-1)], n$ is number of individuals of a particular species, $D$ is diversity index, and $N$ is the total number of individuals present in the entire sample, Simpson's index of diversity $(D=1 / 2$ is diversity index), Simpson's reciprocal index $=(1 / D)$ and Pielou's index for species evenness $\left(J=H^{\prime} /\right.$ In $\left.S\right)$ (Pielou, 1969) Where $H^{\prime}$ is species diversity index and $S$ is the total number of species. Statistical analysis of the data was performed with a Statistical Package for the Social Sciences (SPSS, 2007). One-way ANOVA was applied to understand the difference in variation among species, months, and sampling stations, and the significance was set at 0.05 .

\section{RESULTS AND DISCUSSION Results}

A total 3251 ûsh specimens, representing 11 orders, 15 families, and 28 species, were captured in the New Calabar River (Table 1). The order Perciformes was identified as the most abundant represented five families while the remaining had one family each. The family Cichlidae was the most diverse, representing seven species, and other notable families were Alestidae, Clupeidae and Mugilidae, representing three species each. The fish community in the sampled areas included freshwater fish species (12), brackish fish species (3), and marine fish species of the Atlantic Ocean (13) . The exclusively freshwater species were mainly of cichlids (7), alestids (3), and one species each of fish families of Claroteidae, Notopteridae, and Monodactylidae (Table 1).

Table1. Fish species caught by gill net in the New Calabar River

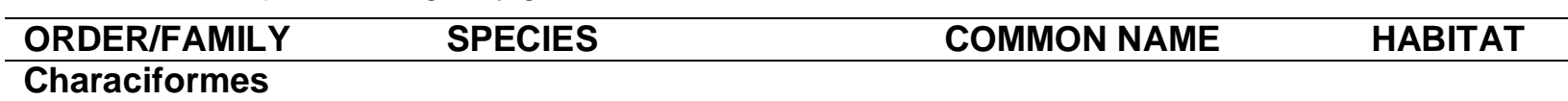

ALESTIDAE

Carangiformes

CARANGIDAE

Cichliformes

CICHLIDAE

\section{Perciformes}

GERREIDAE

LUTJANIDAE

MONODACTYLIDAE ELEOTRIDAE
Brycinus nurse

Brycinus macrolepidotus

Brycinus longipinnis

Caranx hippos

Trachinotus teraia

Coptodon dageti

Coptodon zillii

Coptodon guineensis

Sarotherodon melanotheron

Sarotherodon galilaeus

Chromidotilapia guentheri

Hemichromis fasciatus

Eucinostomus melanopterus

Lutjanus agennes

Monodactylus sebae

Bostrychus africanus
Characin nurse tetra

Large scale robber

Long fin tetra

Freshwater

Freshwater

Freshwater $\begin{array}{ll}\text { Black tailed trevally } & \text { Marine } \\ \text { Shortfinpompano } & \text { Marine }\end{array}$

Five spot tilapia

Red belly tilapia

Guinean tilapia

Black chin tilapia

Mango tilapia

Guenther mouth brooder

Banded jewel fish
Freshwater

Freshwater

Freshwater

Freshwater

Freshwater

Freshwater

Freshwater 


\begin{tabular}{|c|c|c|c|}
\hline $\begin{array}{l}\text { SCIAENIDAE } \\
\text { Pleuronectiformes }\end{array}$ & Pseudotolithus elongatus & Bobocroaker & Marine \\
\hline $\begin{array}{l}\text { BOTHIDAE } \\
\text { Scombriformes }\end{array}$ & Citharichthys spilopterus & Bay whiff & Marine \\
\hline $\begin{array}{l}\text { SPHYRAENIDAE } \\
\text { Osteoglossiformes }\end{array}$ & Sphyraena barracuda & Great barracuda & Marine \\
\hline $\begin{array}{l}\text { NOTOPTERIDAE } \\
\text { Elopiformes }\end{array}$ & Xenomystus nigri & African brown knife fish & Freshwater \\
\hline ELOPIDAE & Elops lacerta & West African lady fish & Brackish \\
\hline Mugiliformes & & & \\
\hline $\begin{array}{l}\text { MUGILIDAE } \\
\text { Siluriformes }\end{array}$ & $\begin{array}{l}\text { Liza falcipinnis } \\
\text { Liza grandisquamis } \\
\text { Mugil cephalus }\end{array}$ & $\begin{array}{l}\text { Sickle fin mullet } \\
\text { Large scaled mullet } \\
\text { Stripped mullet }\end{array}$ & $\begin{array}{l}\text { Marine } \\
\text { Marine } \\
\text { Marine }\end{array}$ \\
\hline $\begin{array}{l}\text { CLAROTEIDAE } \\
\text { Clupeiformes }\end{array}$ & Chrysichthys nigrodigitatus & Mud fish & Freshwater \\
\hline CLUPEIDAE & $\begin{array}{l}\text { Sardinella maderensis } \\
\text { Ethmalosa fimbriata } \\
\text { Ilisha africana }\end{array}$ & $\begin{array}{l}\text { Madeiran sardine } \\
\text { Bong shad } \\
\text { African ilisha }\end{array}$ & $\begin{array}{l}\text { Marine } \\
\text { Marine } \\
\text { Marine }\end{array}$ \\
\hline
\end{tabular}

\section{Monthly Abundance and Distribution}

The monthly representation of fish species recorded in this study is presented in Table 2 . There were differences in the number of fish species caught in each month with the highest recorded in July 2018 (22 species) followed closely by June 2018 with 21 species and the lowest in February with only 17 species caught. There were major differences among months and within species $(p<0.05)$. Prominent among the fish caught monthly include Liza falcipinnis, Mugil cephalus, Sarotherodon melanotheron, Sarotherodon galilaeus, Coptodon guineensis, and Sardinella maderensis, whereas Lutjanus agennes and Xenomystus nigri were at the peak of the rainy season in July only. Mugil cephalus and Liza species were abundant throughout the months apart from the months of June and July. The marine and brackish fish species were dominated from February to May while June to July freshwater species was prevalent.

Relative abundance of fish species across the stations in the New Calabar River are presented in
Table 3. The results revealed that station 2 had the highest fish species with $36 \%$ of the total fish catches followed closely by station 1 (35\%), while station 3 had 29\% (Fig. 2). Overall, 14 species were common in all the three stations and comprised of Brycinus nurse, Caranx hippos, Chrysichthys nigrodigitatus, Coptodon dageti, Coptodon zillii, Coptodon guineensis, Ethmalosa fimbriata, Liza facipinnis, Liza grandisquamis, Monodactylus sebae, Mugil cephalus, Sarotherodon galilaeus, and Sarotherodon melanotheron (Table 3). The following five species; Xenomystus nigri, Pseudotolithus elongatus, Ilisha africana, Citharichthys spilopterus, and Bostrychus africanus were present only in station 1 (Table 3). Apart from Xenomystus nigri, which is the primary freshwater species, the remaining 4 species are peripheral freshwater and marine water fishes. The mean catch per unit effort $(C p U E)$ in Table 4 reveals that the minimum and maximum CpUE values were found to be $3.15 \pm 0.2 \mathrm{~kg}$ unit- ${ }^{1}$ day- ${ }^{-1}$ for Station 2 and $4.85 \pm 0.6 \mathrm{~kg}$ unit- $^{-1}$ day $^{-1}$ recorded for Station 3. 


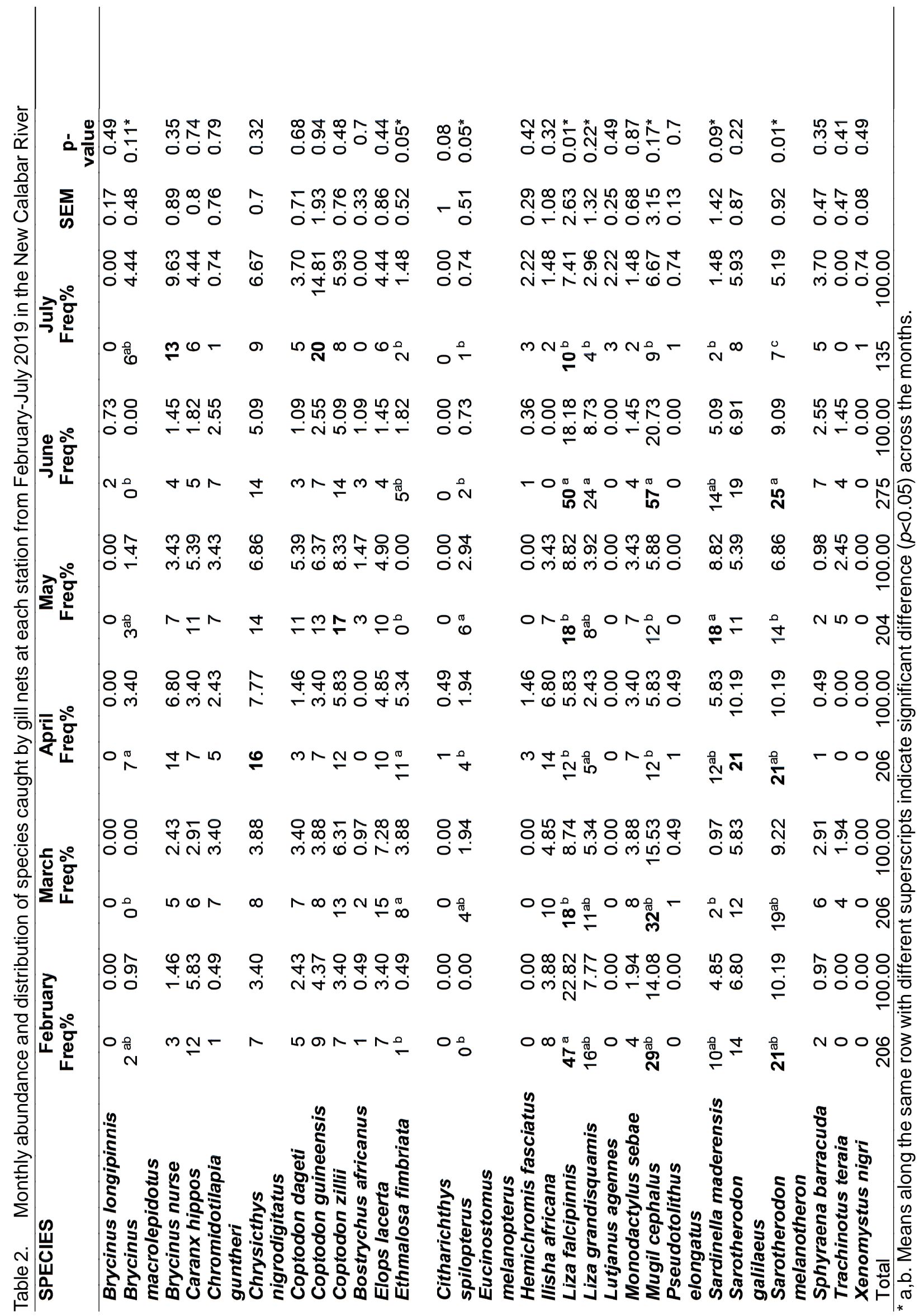


Table 3. Relative abundance of fish species across the stations

\begin{tabular}{|c|c|c|c|c|c|c|c|c|}
\hline Fish species & Freq $\%$ & 1 & Freq\% & & Freq\% & 3 & SEM & $p$-value \\
\hline Brycinus longipinnis & 2 & 0.47 & 0 & 0.00 & 0 & 0.00 & 0.17 & 0.41 \\
\hline Brycinus macrolepidotus & 16 & 3.74 & 2 & 0.45 & 0 & 0.00 & 0.88 & 0.13 \\
\hline Brycinus nurse & 31 & 7.24 & 3 & 0.67 & 12 & 3.35 & 1.81 & 0.30 \\
\hline Caranx hippos & 11 & 2.57 & 16 & 3.59 & 20 & 5.59 & 1.45 & 0.85 \\
\hline Chromidotilapia guntheri & 16 & 3.74 & 12 & 2.69 & 0 & 0.00 & 0.87 & 0.15 \\
\hline Chrysicthys nigrodigitatus & 24 & 5.61 & 15 & 3.36 & 29 & 8.10 & 1.84 & 0.77 \\
\hline Coptodon dageti & 1 & 0.23 & 8 & 1.79 & 25 & 6.98 & 1.47 & 0.25 \\
\hline Coptodon guineensis & 35 & 8.12 & 9 & 2.02 & 21 & 5.87 & 2.21 & 0.94 \\
\hline Coptodon zillii & 12 & 2.80 & 28 & 6.28 & 31 & 8.66 & 2.03 & 0.64 \\
\hline Bostrychus africanus & 9 & 2.10 & 0 & 0.00 & 0 & 0.00 & 0.54 & 0.14 \\
\hline Elops lacerta & 9 & 2.10 & 25 & 5.61 & 18 & 5.03 & 1.7 & 0.67 \\
\hline Ethmalosa fimbriata & 1 & 0.23 & 21 & 4.71 & 5 & 1.40 & 1.26 & 0.25 \\
\hline Eucinostomus melanopterus & 1 & 0.23 & 16 & 3.59 & 0 & 0.00 & 0.89 & 0.11 \\
\hline Hemichromis fasciatus & 4 & 0.93 & 3 & 0.67 & 0 & 0.00 & 0.29 & 0.37 \\
\hline Ilisha africana & 0 & 0.00 & 41 & 9.19 & 0 & 0.00 & 2.7 & 0.21 \\
\hline Liza facipinnis & 81 & 18.93 & 47 & 10.54 & 27 & 7.54 & 5.28 & 0.62 \\
\hline Liza grandisquamis & 41 & 9.58 & 10 & 2.24 & 17 & 4.75 & 2.27 & 0.38 \\
\hline Lutjanus agennes & 2 & 0.47 & 0 & 0.00 & 1 & 0.28 & 0.18 & 0.57 \\
\hline Monodactylus sebae & 8 & 1.87 & 6 & 1.35 & 18 & 5.03 & 1 & 0.47 \\
\hline Mugil cephalus & 68 & 15.89 & 41 & 9.19 & 42 & 11.73 & 4.74 & 0.83 \\
\hline Pseudotolithus elongatus & 0 & 0.00 & 3 & 0.67 & 0 & 0.00 & 0.18 & 0.14 \\
\hline Sardinella maderensis & 0 & 0.00 & 38 & 8.52 & 20 & 5.59 & 2.33 & 0.27 \\
\hline Sarotherodon galilaeus & 22 & 5.14 & 36 & 8.07 & 27 & 7.54 & 2.25 & 0.84 \\
\hline Sarotherodon melanotheron & 24 & 5.61 & 52 & 11.66 & 31 & 8.66 & 3.02 & 0.66 \\
\hline Sphyraena barracuda & 0 & 0.00 & 9 & 2.02 & 14 & 3.91 & 0.92 & 0.32 \\
\hline Trachinotus teraia & 8 & 1.87 & 5 & 1.12 & 0 & 0.00 & 0.53 & 0.33 \\
\hline Xenomystus nigri & 1 & 0.23 & 0 & 0.00 & 0 & 0.00 & 0.08 & 0.41 \\
\hline Total & 428 & 100.00 & 446 & 100.00 & 358 & 100.00 & & \\
\hline
\end{tabular}

Table 4. Catch per Unit Effort (CpUE)

\begin{tabular}{|c|c|c|c|c|c|}
\hline \multicolumn{2}{|c|}{$\begin{array}{l}\text { Station } 1 \\
\left.\text { (Kg unit- }{ }^{-1} \text { day- }{ }^{1}\right)\end{array}$} & \multicolumn{2}{|c|}{$\begin{array}{l}\text { Station } 2 \\
\text { (Kg unit-1 day-1) }\end{array}$} & \multicolumn{2}{|c|}{$\begin{array}{l}\text { Station } 3 \\
\text { (Kq unit-1 dav- }{ }^{1} \text { ) }\end{array}$} \\
\hline Mean $\pm S E$ & Range & Mean \pm SE & Range & Mean \pm SE & Range \\
\hline $3.95 \pm 0.6$ & $2.65-5.88$ & $3.15 \pm 0.2$ & $2.89-6.11$ & $4.85 \pm 0.6$ & $3.01-5.95$ \\
\hline
\end{tabular}

The results of diversity indices revealed great variation in all the values recorded in the three sampling stations (Table 4). Individual rarefaction curves and percentage species richness in each station (Figure 2 and Table 4) revealed that community diversity was the highest in Station 1 with 24 species accounting for $37 \%$ of all fish fauna in the river, followed closely by Station 2 with 23 species (36\%) and Station 3 with 17 species (27\%). Further results revealed the calculated catch diversity, Shannon-wiener index, ranged from 2.64 to 2.82 with the highest value of 2.82 recorded in Station 2, followed by 2.71 and 2.64 at Station 3 and Station 1, respectively. The alpha diversity profiles revealed the similarities and differences across sampling stations (Figure 3). Station 1 had the highest Simpson's index value of 0.10 , followed by both Station 2 and Station 3 with 0.07 each (Table 4). Simpson's index of diversity also varied between 0.90 and 0.93 , while the Simpson's reciprocal index values ranged from 1.08 to 1.11 . The minimum Pielou's evenness index $(\mathcal{J})$ value was 0.82 , recorded at Station 1 , and the maximum value of 0.95 was recorded at station3. 


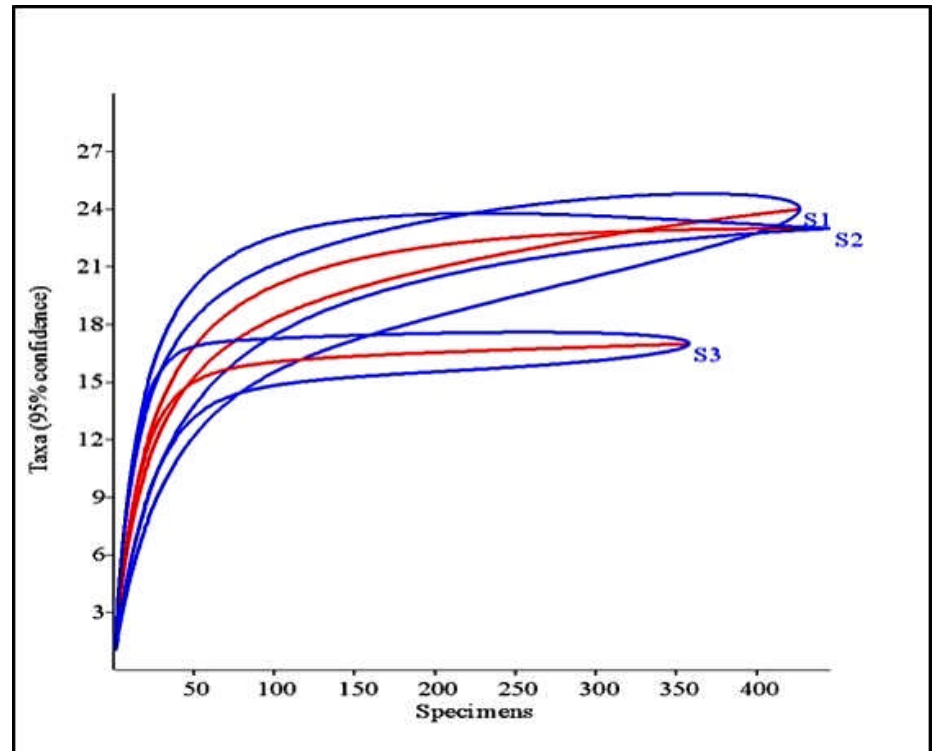

Figure 2. Rarefaction curves of fish communities in the New Calabar River.

Table 5. Diversity indices of fish species caught by gill nets

\begin{tabular}{llllllllll}
\hline Station & $\begin{array}{l}\text { Percentage } \\
\text { of fish } \\
\text { species } \\
\text { caught per } \\
\text { station }\end{array}$ & $\begin{array}{l}\text { Percent- } \\
\text { age } \\
\text { Species } \\
\text { richness }\end{array}$ & $\begin{array}{l}\text { Species Indices } \\
\text { Number } \\
\text { of } \\
\text { species }\end{array}$ & $\begin{array}{l}\text { Number } \\
\text { of } \\
\text { individu- } \\
\text { al }\end{array}$ & $\begin{array}{l}\text { Simpson's } \\
\text { Index }\end{array}$ & $\begin{array}{l}\text { Simpson's } \\
\text { Index of } \\
\text { diversity }\end{array}$ & $\begin{array}{l}\text { Simpson's } \\
\text { Reciprocal } \\
\text { Index }\end{array}$ & $\begin{array}{l}\text { Shannon- } \\
\text { Weiner } \\
\text { Diversity } \\
\text { Index }\end{array}$ & $\begin{array}{l}\text { Pielou's } \\
\text { Evenness } \\
\text { Index }\end{array}$ \\
\hline 1 & 31 & 37 & 24 & 428 & $0.10^{* *}$ & $0.09^{*}$ & $1.11^{* *}$ & $2.64^{*}$ & $0.82^{*}$ \\
2 & 29 & 36 & 23 & 446 & $0.07^{*}$ & $0.93^{* *}$ & $1.08^{*}$ & $2.82^{* *}$ & 0.90 \\
3 & 25 & 27 & 17 & 358 & $0.07^{*}$ & $0.93^{* *}$ & $1.08^{*}$ & 2.71 & $0.95^{* *}$ \\
\hline
\end{tabular}

${ }^{*}$ lower calculated values ${ }^{* *}$ higher calculated values

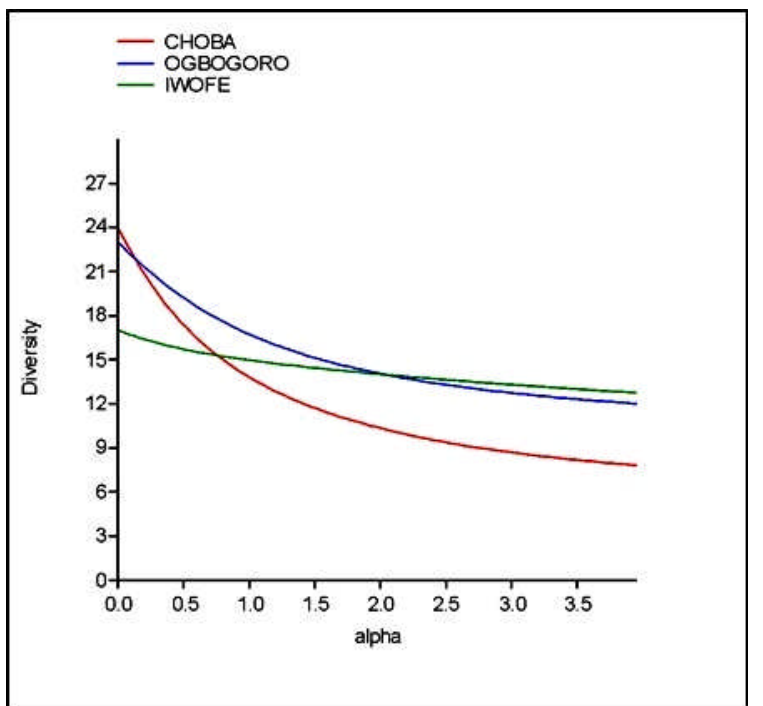

Figure 3. Diversity profile for the community of fish in all stations.

\section{Discussion}

The results from this present study have shown that the river supports diverse fish fauna. The river condition reflects food availability, environmental factors, and productivity. In all, 28 fish species of 11 orders belonging to 15 families were recorded in the present study. The fish fauna was similar to other studies conducted in the same river. For example, Dienye et al. (2018) sampled the cast nets catch reported 11 fish families and 26 fish species, while Ibim et al. (2016) identified 61 species, belonging to 54 genera, 41 families, and 15 orders of the catch using different fishing gears. The results of the survey show the importance of the order Perciformes as the dominant fish belonging to five fish families. The 
Perciformes (perches and allies) is the largest vertebrate order with over 11,000 species found throughout fresh and marine waters of the world (Snoeks et al., 1997).

The dominating fish family was Cichlidae, represented by six species. This corroborated the findings of Lévêque (1997), who reported that Cichlidae was the most diverse fish family in Africa, with at least 870 species. The diversity of cichlids in recent times has been a subject of controversy with over 1000 species identified in the three large East African lakes (Stiassny \& Meyer, 1999). The present findings were supported by Olopade \& Dienye (2018) who reported the dominance of cichlids in the New Calabar River. Other notable families were Alestidae, Clupeidae, and Mugilidae represented by three species. Mullets (Mugilidae), sardine, and bonga (Clupeidae) were classified as major contributing fish families in the brackish water system in Nigeria (Fagade \& Olaniyan, 1974; Amadi, 1991). The two fish families are mostly marine economically valuable fishes but often found entering estuaries and tidal rivers (Fagade \& Olaniyan, 1974, Burgis \& Symoens, 1987 and Amadi, 1990). A fish might alter its residence during different parts of its life history, most importantly diadromous fishes that require freshwater for reproduction.

Most of these fish species are migratory species moving from the brackish and marine waters to the river for spawning. Olopade et al. (2018) described the New Calabar River as a partially mixed estuary indicating that their fish fauna is more related to the coastal and marine fishes than to the typical riverine fish fauna. Six of the species recorded in the current study: Citharichthys spilopterus, Eucinostomus melanopterus, Xenomystus nigri, Pseudotolithus elongatus, Bostrychus africanus, and Brycinus longipinnis, were not listed in Dienye et al. (2018). The following important fish species were conspicuously missing in the current study but were reported in Dienye et al. (2018), who used cast nets in the same river. These were Ethmalosa fimbriata, Lutjanus dentatus, Chrysichthys aluuensis, Pomadasys jubelini, and Pelmatolapia mariae. This could be attributed to the habitat of these species that make them uncatchable by gill nets.

The findings of this analysis indicate a monthly variation in the number of fish species captured by gill nets. King (1991) opined that the economically valuable fish species in the waters of the Niger Delta are landed all year round by artisanal fishers, but there is a monthly variability in their abundance. The monthly catch distribution was the highest in July and June, while the lowest in February. The variations in the habitat condition associated with the peak of rainfall, i.e. June to July, and the ebb of rainfall from February to May show species differences in the catch during those months. The high catch rate of Liza falcipinnis, Sarotherodon melanotheron, Sarotherodon galilaeus, Coptodon guineensis, and Sardinella maderensis in all the months seems to indicate these species as exploitable stocks. Also, these species are known for tolerance to variations in salinity and other physical features (Soyinka, 2010). Lutjanus agennes and Xenomystus nigri were recorded only in July at the peak of the rainy season while Mugil cephalus and the Liza species, which have been abundant throughout the months, were not caught in June and July, suggesting that rainfall plays a major role in the distribution of the fish species in the river.

Gillnet $C p U E$ has been used as an index of fish biomass or density in numerous ecological and fisheries studies (Olin et al., 2002). The range of CpUE in this study was $3.15 \pm 0.2-4.85 \pm 0.6 \mathrm{~kg}$ unit- $^{-1}$ day $^{-1}$ recorded for Station 2 and Station 3, respectively. The differences in (CpUE) between the sites could be attributed to fishing areas and fishing duration (Harley et al., 2001). Fish availability, density, and mobility are important factors influencing fishing efficiency (Laevastu \& Favorite, 1988).

Fish communities in the riverine system typically follow a pattern of increasing species richness, diversity, and abundance from upstream to downstream (Bayley \& Li, 1994; Grando, 2000). This is also in line with Lakra et al. (2010). However, our findings in this study showed a sharp contrast to the typical pattern. For example, the results showed higher percentages of fish species, species richness, and number of species in Station 1 and Station 2 (upper and middle reaches) than Station 3 (lower reaches). The pattern found in this river suggests cumulative temporal and spatial effects of habitat loss or environmental degradation in the lower zone (Scrimgeour \& Chambers 2000; Wolter et al., 2000). Both habitat loss and environmental degradation in terms of sand extraction for construction of roads and buildings and water pollution are a common feature in the study area (Horsefall \& Spiff 1998; Ajana, 2003). Oil spill incidents are common in various parts of the river particularly in the lower reaches because of oil bunkering as a consequence of deliberate vandalism or theft of oil (Amnesty International, 2009). Adewale (1985) reported that it has deleterious effects on living resources, impairs water quality and creates imbalance in the ecosystem. The adverse effects of crude oil pollution are largely responsible for the downward trend in fish catches, generally recorded by most artisanal fishers operating in waters prone to 
oil pollution (Adewale, 1985). A fish community becomes more dissimilar as the stress increases and accordingly species diversity decreases with poor water quality. Low fish species recorded in Station 3 could also be associated with the extreme spatial variability in salinity, with a range of near zero at the tidal limit of tributary rivers to $3.4 \%$ at the estuary mouth (Conner et al., 2007).

Shannon-Wiener diversity index $\left(\mathrm{H}^{\prime}\right)$ values ranged from 2.64 to 2.82 , indicating that the species of fish at each station were similar. However, the values recorded in this study were higher than those reported by Emmanuel \& Modupe (2010), who reported 1.87 to 2.02 in three tributaries of River Ore in the same region in Nigeria. Belaluzzaman (1995) recorded the $H^{\prime}$ as 1.02-4.65 from the Bakkhali River estuary. According to Biligrami (1988), the $H^{\prime}$ of the present findings represents light pollution based on the assortment of the degree of pollution. The Simpson index maximum and minimum values were 0.10 and 0.07 . The Simpson value portrays the dominance of species and it is inversely related to ShannonWiener diversity index and values can come more than 1 unlike in other index, where the values will be varied from 0 to 1 . Both Simpson's Reciprocal and Index Pielou's evenness index $(\mathcal{S})$ value values were very close to 1 , indicating that fish diversity and community were in good condition.

\section{CONCLUSIONS}

The present study is a preliminary survey of fish species associated with gill net fishery in the New Calabar River. The fish fauna diversity of the New Calabar River is mainly marine fish species and out of the 29 species caught only 12 are exclusively freshwater fishes. Species composition and fisheries diversity are high. The gill nets' catch ability were dominated by four species, Liza facipinnis, Mugil cephalus, Sarotherodon melanotheron, and Sarotherodon galilaeus. The diversity index values recorded in this study were within recommended values. In order to increase the abundance of fish and guard against loss of diversity from the New Calabar River, there is a need to conserve and manage fish biodiversity through effective strategies to control oil pollution and other human activities impacting the river ecosystem.

\section{ACKNOWLEDGEMENTS}

The authors express their sincere thanks to the fishermen in the New Calabar River for providing valuable field assistance.

\section{REFERENCES}

Abowei, J. F. U. (2000). Aspects of the fisheries of the lower Nun River. Ph.D. Dissertation, University of Port Harcourt, Port Harcourt, 248pp.

Adesulu, E. A., \& Sydenham, D. H. J. (2007). The fresh water and fisheries of Nigeria. Macmillan Nigeria Publishers, Lagos. 397 pp.

Adewale, O. (1985). Judicial attitude to environmental hazards in Nigerian oil industry: Proceedings of An International Seminar on the Petroleum Industry and Nigeria Environment, Port Harcourt, pp, 35-40.

Ajana, A.M. (2003). Economic development of the Niger Delta: The role of fisheries. A paper presented at the first Niger Delta stakeholder's Agricultural forum, organized by Niger Delta Development Commission, Port-Harcourt

Amadi, A. A. (1990). A comparative ecology of estuaries in Nigeria. Hydrobiologia. 208, 27-28. DOI: $10.1007 / \mathrm{BF} 00008440$

Amadi, A. A. (1991). The coastal and marine environment of Nigeria. Aspects of ecology and management. NIOMR Technical Paper 76, 1-34.

Amnesty International. (2009). Petroleum, Pollution, and Poverty in the Niger Delta. London

Bayley, P. \& Li, H. (1994). Riverine fisheries. In: The river handbook: Hydrological and ecological principles, Calow, P. and G.E. Petts, (Eds.). Blackwell, Boston, pp: 251-281.

Belaluzzaman, A.M. (1995). Ecology of the intertidal macro benthic fauna in Cox's Bazar coastal area, Bangladesh. M.Sc. Thesis, Institute of Marine Sciences, University of Chittagong, Bangladesh, pp. 53-55.

Biligrami, K. S. (1988). Biological monitoring of rivers, problems and prospects in India. Aquatic Ecotoxicology, pp. 245-250

Burgis, M. J. \& Symoens. J. J. (1987). African wetlands and shallow water bodies. Directory Travaux et Documents de IORSTOM, 210 ORSTOM Bondy France 650pp.

Clarke, D. R., \& King. P.E. (1986). The estimation of gillnet selection curves for Atlantic herring 
(Clupeaharengus L.) using length-girth relations. Journal du Conseil Permanent International pour l'Exploration de la Mer, 43, 77-82

Conner, W. H., Doyle T. W., \& Krauss, K. W. (2007). Ecology of Tidal Freshwater Forested Wetlands of the Southeastern United States. Springer Science and Business Media. p. 36. ISBN 978-14020-5095-4.

Dienye, H. E., Olopade, O. A., \& Toby. S. A. (2018). Species composition and diversity of cast net fisheries in New Calabar River, Niger Delta. Nigeria. Journal Biodiversity Conservation Bioresources Management, 4(1), 19-26. https://doi.org/ 10.3329/jbcbm.v4i1.37873

Emmanuel, L. O., \& Modupe, O.O. (2010). Fish Diversity in three tributaries of river Ore, South West, Nigeria. World Journal of Fish and Marine Sciences, 6, $524-531$.

Fagade, S.O., \& Olaniyan, C. I. O. (1974). Seasonal distribution of the fish fauna of the Lagos lagoon. Bulletin del'Institut fondamental d'Afrique noire. Série A, 36(1), 244-254.

FAO (2007). Fishery and Aquaculture Country Profile. Nigeria 2007 Country Profile Sheets. In. FAO Fisheries and Aquaculture Department [online]. Rome. Updated 1 November 2018. [Cited 8 December 2018]

Froese, R., \& Pauly, D. (2010). Fish Base. World Wide Web electronic publication.www.fishbase.org, version (01/2010). Captured on 24 Mar 2010

Garcia, S., \& Demetropoulos, A. (1986). Management of Cyprus fisheries. FAO Fisheries Technical Paper 250, 40p.

Grando, C. (2000). Ecology of comunidades the paradigm of freshwater pisces. University of Seville Secretariat Publications, Sevilla.

Harley, S. J., Myers, R. A., \& Dunn, A. (2001). Is catch-per-unit-effort proportional to abundance? Canadian Journal of Fisheries and Aquatic Sciences, 58, 1760-1772. https://doi.org/ 10.1139/f01-112

Horsefall, M.J., \& Spiff, A. T. (1998). Principles of Environmental Pollution. $1^{\text {st }}$ Edn. Metro Prints, Port Harcourt, pp: 212-217.
Ibim, A. T., Gogo, O. O., \& Igbani, F. (2016). The Ichthyofaunal Assemblage of the Lower and Upper Reaches of New Calabar River, Rivers State, Niger Delta, Nigeria. Journal Environment Earth Science, 6(9), 186-197.

King, R. P. (1991). The biology of tilapia mariae Bovlenger 1899 (PERCIFORMES: Cichlidae) in a Nigeria rainforest stream. Ph.D. Thesis. Department of Zoology, University of Port Harcourt, Nigeria. 289 pp.

Lakra, W. S., Sarkar, U. K., Kumar, R. S., Pandey, A., \& Dubey, V.K. (2010). Fish biodiversity, habitat ecology and their conservation and management issues of a tropical River in Ganga basin, India. Environmentalist, 30(4), 306-319. DOI: 10.1007/ s10669-010-9277-6

Laevastu, T., \& Favorite, F. (1988). Fishing and stock fluctuation. Surrey, England: Fish. News Books. 49-71.

Lévêque, C. ed. (1997). Biodiversity dynamics and conservation: The Freshwater Fish of Tropical Africa. Cambridge (UK): Cambridge University Press. 438pp.

Olin, M., Rask, M., Ruuhijärvi, J., Kurkilahti, M., AlaOpas, P., \& Ylönen, O. (2002). Fish community structure in mesotrophic and eutrophic lakes of southern Finland: the relative abundances of percids and cyprinids along a trophic gradient. Journal of Fish Biology, 60, 593-612. https:// doi.org/10.1111/j.1095-8649.2002.tb01687.x

Olopade, O.A., Taiwo, I.O., \& Dienye, H.E. (2017a). Management of overfishing in the inland capture fisheries in Nigeria. Limno Fish, 3(3), 189-194. doi: 10.17216/LimnoFish.335549

Olopade, O. A., Sinclair, N. G., \& Dienye, H.E. (2017b). Fish catch composition of selected small scale fishing gears used in the Bonny River, Rivers State, Nigeria. Journal of Fisheries, 5(1), 455-460. http://dx.doi.org/10.17017/jfish.v5i1.2017.173

Olopade, O.A., \& Dienye, H.E. (2018). Distribution and abundance of cichlids in the New Calabar River, Nigeria. Journal of Fisheries, 6(2), 617-622. DOI: 10.17017/jfish.v6i2.2018.318

Olopade, O. A., Dienye, H. E., \& Eyekpegha, A. (2018). Length frequency distribution, length-weight relationship and condition factor of cichlid fishes 
(Teleostei: Cichlidae from the New Calabar River, Nigeria. Iranian Journal of Ichthyology, 5(1), 7480.

Pielou, E. C. (1969). An introduction to mathematical ecology. Witley-Interscience, New York, 385 pp.

Sarý, H.M., Balýk, S., Ustaoðlu, M.R., \& Ýlhan, A. (2006). Distribution and ecology of freshwater ichthyofauna of Biga Peninsula, Nort-Western Anatolia, Turkey. Turkish Journal Zoology, 30, 3545.

Schneider, W. (1990). FAO species identification sheets for fishery purposes. Field Guide to the Commercial Marine Resources of the Gulf of Guinea. FAO Regional Office for Africa, Rome, 268 p.

Shannon, C. E., \& Weaver, W. (1949). The Mathematical Theory of Communication. Urbana: University of Illinois Press, Urbana, 117pp.

Smith, C.L. (1978). Coral reef area and the contribution of reefs to processes and resources of the world's oceans. Nature, 273, 225-226.
Snoeks, J., Harrison, I. J., Stiassny, M .L. J., \& Leveque, C. (1997). The status and distribution of freshwater ûshes biodiversity and conservation. In: The Freshwater Fish of Tropical Africa. Cambridge University Press, 432 pp.

Solarin, B.B., Udolisa, R.E.K., Omotayo, N. O., Lebo, P. F., \& Ambrose, E.F. (2003). Hook, Line and Sinker. Samudra, July, 41-45.

Soyinka, O. O., Kutona, M. P., \& Ayo-Olalus, C.I. (2010). Seasonal distribution and richness of fish species in the Badagry Lagoon, south-west Nigeria. Estonian Journal of Ecology, 59(2), 147157.

SPSS, (2007) Statistical Package for Social Science. Advanced Statistics 15.0. Chicago, SPSS.

Stiassny, M. L. J., \& Meyer, A. (1999). Cichlids of the rift lakes. Scientiûc American, 280, 64-91.

Wolter, C., Minow, J., Vilcinskas, A., \& Grosch, U. (2000). Long-term effects of human inûuence on ûsh community structure and ûsheries in Berlin water: an urban water system. Fisheries Management and Ecology, 7, 97-10. 